\title{
Model of Control of Financial Results of the Enterprise
}

\author{
Alex Ivanovich Borodin \\ Moscow State University of Food Productions Russia, 125080, Moskow, Volokolamskoye h., 11 \\ E-mail: aib-2004@yandex.ru \\ Nataliya Nicolaevna Shash
}

National Research University 'Higher School of Economics', Russia, 101000, Moskow, Myasnitskaya st., 20

E-mail: nat_vshu@mail.ru

\section{Arsen Azidovich Tatuev}

Moscow State University of Food Productions, Russia, 125080, Moskow, Volokolamskoye h., 11

E-mail: arsen.tatuev@mail.ru

Svetlana Sergeevna Galazova

North-Ossetian State University named after K. L. Khetagurov Russia, 362015, Republic of North Ossetia-Alania, Vladikavkaz, Vatutina street, d. 46 E-mail: hss@mail.ru

\section{Violetta Valerievna Rokotyanskaya}

Moscow State University of Food Productions, Russia, 125080, Moskow, Volokolamskoye h., 11 E-mail: rokotyanskay_V_V@mail.ru

Doi:10.5901/mjss.2015.v6n4s2p578

\begin{abstract}
In article it is shown that on formation of financial result of the enterprise have impact a row multidirectional both internal, and external factors which define a final indicator - profit (loss) of the enterprise. As a result, the model in which all essential factors having impact on profit of the enterprise, engaged in electric power generation were included was constructed. The constructed model at methodological level solves a problem of identification of reserves of receiving profit of the enterprise. Moreover, the model allows to supervise financial result of the enterprise by identification of the factors which have made negative impact on financial result in the certain period. As a result, the constructed model allows to carry out an assessment of the actions connected with increase or reduction of indicators, entering into model. Therefore, the developed model gives opportunity to supervise financial result both all generating enterprise as a whole, and the separate station including some blocks, and also the separate generating block.
\end{abstract}

Keywords: financial results of the enterprise, enterprise profit, Dupont's model, external control, internal control

\section{Introduction}

In world practice for the purpose of control of financial results the model Dupont which investigates dependences between the various indicators influencing economic profitability of the enterprise is widely used. Let's construct economic-mathematical model of control of financial results of the enterprise of the power branch which primary activity is electric power generation. The major factor influencing the income, is production capabilities of the enterprise during time which in turn depends on the established electric power at the enterprise and a number of hours in the considered period. The second factor influencing the income, the rated capacity efficiency which characterizes level of loading of available capacities in the considered period is. The third factor defining the income of the generating enterprise, the coefficient of useful holiday of the electric power is. The fourth factor included in model of the income of the generating enterprise, the price of the released electric power in the wholesale market of the electric power which changes owing to enterprise work 
in basic or peak modes is.

As in market conditions, and in a planned economy, the monitoring function is essential in the management of enterprise profit. Different approaches to the control of the company's financial results can be divided into two main areas:

- External control;

- Internal control.

It should be noted that two different approaches to the control of financial results are determined by different objectives in the control (Borodin \& Shash \& Belokrylova, 2013).

External control is usually associated with activities of the state institutions of its fiscal function. Control comes to a range of techniques, which are stated in the laws that regulate the formation, reflection and taxation of financial results of the company. Tax authorities play pivotal role in the control of financial results of the company and also systematically carry out external control of the financial results of the company as a taxable income. Also, external control can be carried out on the initiative of the enterprise creditors (banks, large suppliers). Such control generally comes to carrying out the enterprise external audit or acquisition of times-personal data about its activity (Nechitaylo, 2011).

\section{Method}

Internal control of financial results of the enterprise has different objectives and usually carried out in order to find ways to improve enterprise management, to raise funds to increase financial results economic agent, and as a result, execute the main objective of financial management - raise in welfare the owners of the company (Uliyanov, 2010).

A number of different directions of the factors, both internal and external, which define resultant of income (loss) of the enterprise, influences financial results of the enterprise. Economic and mathematical models are used as effective tools for monitoring the financial performance of the company in foreign countries and Russian practice, allowing revealing of reserves to increase the profits of the enterprise (Borodin \& Shash \& Goloshchapova, 2013) DuPont model is widely used to monitor the financial performance all over the world (Borodin \& Katkov, 2010). This model was first used be managers of DuPont Company in order to study the relation between the various factors influencing the economic viability of the enterprise. It should be noted that the control of the financial results of the company can be carried out by the modulus of largest financial results, as well as relative value, characterizes profitability. In condensed form DuPont formula is as follows:

$$
R_{A}=R_{S} \times T_{A},
$$

where $R_{A}$ - the profitability of the company's assets; $R_{S}$ - Return on sales; $T_{A}$ - Asset turnover ratio.

In the extended form of DuPont's formula is as follows:

$$
R_{C}=R_{S} \times T_{A} \times A / C
$$

where $R_{C}$ - the return on equity; $\mathrm{A}$ - assets of the company; $\mathrm{C}$ - Equity.

Russian scientists and economists also pay considerable attention to construction of multifactor models to monitor the financial performance of the company (Bogatin \& Shvandar, 1998; Krylov \& Vlasova \& Zuravkova, 2005).

For enterprises producing one type of product offered the following models:

$$
I=\frac{b\left(p d-K_{N} \cdot r\right)-(1-r)(1+f)}{p-1}
$$

where $\mathrm{I}$ - the index of business profits; $\mathrm{b}$ - the coefficient of variation in production and sales of marketable produce; $p$ - the coefficient of profitability of commercial products in the base period; $d$ - coefficient of variation of prices of commercial products; $K_{N}$ - Coefficient of variation of the variable costs of the reference period in an analyzed period; $r$ the coefficient of the variable costs in the base period; $f$ - coefficient of variation of fixed costs in the analyzed period.

If the formula presented we replace some of indexes with their equivalent, the result will be:

$$
K_{N} \cdot r=g-(1-r) \text {, }
$$

where $g$ - coefficient of variation of the cost of production of the reference period under the influence of a change in its variable components. Now we can get a second parametric model which is matching with the first one. It will have the following form:

$$
I=\frac{b(p d-g)-(1-r)(b-1-f)}{p-1}
$$


Both models are equivalent and the choice of some of them is determined by particular circumstances and the availability of the original information.

Transformation of the models in the model of the companies with diversified production is not difficult (Bogachev, 1993; Borodin \& Shash \& Belokrylova, 2013). It is enough to change the method of calculating the factors included in the parametric model in relation to diversified production.

It should be mentioned that all above-mentioned allow us to monitor the financial performance of the company. However, none of the models takes into account the specifics of the company in various sectors of the economy, making them inapplicable in practice management of specific business entities. In our view, the specific operation of enterprises in various industries in the market conditions is the main criterion, according to which the enterprise should develop the model, which allows monitoring and raising funds in order to increase profitability. The most specific sectors in the economy of any country are natural monopolies, heavy and light industry, enterprises (Ostapenko, 2008).

\section{Results}

Generalization of the monitoring process of financial results for the enterprise of various sectors is impractical because of obvious differences in factors affecting the profit margin. For example, for trade companies the main factor affecting the financial result is the profit margin, which is defined as the difference between the purchase price and the selling price. At the same time, trading companies has virtually no costs associated with the production process. In other words, the main variable costs of trade companies include transport costs, which is (in most cases) appropriate include in the purchase price of the goods. In this case, factors that characterize the process of sale of products, such as the intensity of sales, service speed should be used to evaluate the influence must be used in order to evaluate the influence of each factor (Kuzin \& Uriev \& Shakhdinarov, 2001).

Companies engaged in extraction and mining also have their own specifics, which leads to the existence of factors affecting the financial results. However, it should be noted that the enterprise producing various types of resources, are also particularly significant in the formation of the financial result.

Let us define the economic-mathematical model of financial control of the results in energy industry sector, the main activity of which is electricity generation. To describe the factor model of electricity generating companies often used the traditional approach to the calculation of profit:

$\mathrm{PU}=\mathrm{RU}-\mathrm{VCU}-\mathrm{FCU}$,

where PU - income of the generating company; RU - revenue of generating the company; VCU - variable costs of generating the company; FCY - fixed costs of the generating company.

It should be noted that the revenue and variable costs of the generating company, included in the additive model (6), are treated as separate multiplicative parametric models. Consideration of the formation of revenues and variable costs of the generating company enables to evaluate trends that emerged, and to establish due to what factors there is a change. Calculating of revenues and variable costs was carried out in accordance with a number of requirements:

1. The value of intermediate productive indicator equal to the product of the factors included in the model, which reflect certain aspects of the economic activity of the enterprise;

2. Productive indicator can be presented using qualitative or quantitative characteristics. Identify and describe the factors affecting the income of the enterprise that produces electricity.

The main factor affecting the income of the enterprise is the production capacity of that company for a period of time, which in turn depends on the installed electrical capacity at the plant and the number of hours in the stated period. Manufacturing capabilities are defined as the product of the installed capacity of the company and the number of hours in the stated period. The increase in production capacity causes an increase in the company's income, as large manufacturing facilities are responsible for generating a greater volume of electricity at a constant level of capacity utilization.

The second factor affecting the income is the utilization of installed capacity, which characterizes the level of loading of available capacities in the period under review. Increasing the level of the coefficient in-use of installed capacity entails the production of a larger amount of electricity, and, consequently, the growth of the company's revenue.

The third determinant of the income-generating enterprises, is the efficiency of electricity supply. This indicator shows the volume of the company's needs for electricity. The company that generates electricity, pays special attention to reducing their own needs in electricity, since it allows to have a significant impact on the income of the enterprise. The less their own needs, the more productive supply, and, consequently, income.

The fourth factor included in the model of income-generating enterprises, is the price for the electricity in the wholesale electricity market (WEM), which changes as a result of the enterprise operating in the base or peak mode. 
Work in peak load conditions allows generating company to count on a great price of electricity, however, work in peak modes associated with increased costs in the form of specific fuel consumption. Increasing the price of electricity supplied to the wholesale electricity market, increase the income of the company.

Let us write the equations of the model of income of the generating enterprises.

Production capacity of the enterprise:

$P C=C \times T$,

where PC - production capacity of the enterprise;

$\mathrm{C}$ - installed capacity, mWh;

$\mathrm{T}$ - period duration, $\mathrm{h}$.

Installed capacity utilization rate:

$$
K I U M=\frac{Q P}{P C}
$$

where KIUM - installed capacity utilization rate;

QP - power generation, kWh.

The efficiency of electricity supply:

$$
R U T=\frac{D}{Q P}
$$

where RUT - the efficiency of electricity supply:

D - electricity supply.

Price for the electricity in the WEM:

$$
P E=\frac{R U}{D}
$$

where PE - price for the electricity in the WEM

Revenues of the generating company:

$$
R U=P C \times K I U M \times R U T \times P E=P C \times \frac{Q P}{P C} \times \frac{D}{P C} \times \frac{R U}{D}
$$

\section{Discussion}

Let us identify and describe the factors influencing the variable costs of the company that produces electricity.

The main factor determining variable costs is electricity generation. Fuel consumption used for electricity generation, increase with the volume of production.

The second factor is the specific fuel consumption for the production of one kWh of electricity. This factor is qualitative and characterize both the modes of plant's operation (at peak modes significantly increases fuel consumption) and the technical condition of the power unit and the type of fuel used. When fired on a gas or fuel oil, specific fuel consumption is significantly reduced, but its price is not always reasonable for utilizing these fuels. The increase in specific fuel consumption leads to an increase of total semi-variable costs of electricity generation.

Third factors affecting the company's costs, is the specific cost of the fuel in-use. This indicator reflects both the change in the prices of all fuels used in electricity generation and consumption patterns of different types of fuel (gas, fuel oil, coal). Increasing the price of the unit of fuel increases semi-variable costs of generating electricity (Borodin \& Katkov, 2010; Borodin \& Shash \& Goloshchapova, 2013).

Let us write the equations of the model semi-variable costs of the generating company.

Specific fuel consumption for the production of one kWh of electricity:

$$
F R=\frac{Q F}{Q P}
$$

where FR - specific fuel consumption for the production of one kWh of electricity;

QF - total fuel consumption (t. y. m.).

Specific fuel price:

$$
F P=\frac{C F}{Q F}
$$

where FP - specific fuel price;

CF - fuel price. 
Semi-variable costs of the generating companies:

$V C U=Q P \times F R \times F P=Q P \times \frac{Q F}{Q P} \times \frac{C F}{Q F}$

Semi-fixed costs of generating companies are normalized based on the amount of installed capacity and are included in the model of individual factor.

Thus, the influence of various factors on the profit of power generation enterprises can be represented as follows:

$P U=P C \times K I U M \times R U T \times P E-Q P \times F R \times F P-F C U$

After building the model by the method of elimination, it is possible to observe the impact of each factor on the change of business profits, and, consequently, to identify potential for raising revenue.

Change in profit due to changes in production capacity of the enterprise:

$\triangle P U P C=\triangle P C \times K I U M O \times R U T O \times P E O-Q P O \times F R O \times F P O-F C U 0$.

Change in profit due to changes in capacity factor:

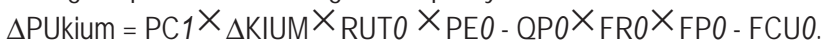

Change in profit due to changes in the efficiency of electricity supply:

$\Delta$ PUrut $=\mathrm{PC}_{1} \times_{\mathrm{KIUM} 1} \times_{\Delta \mathrm{RUT}} \times{ }_{\mathrm{PE} 0}-\mathrm{QPO} \times_{\mathrm{FRO}} \times_{\mathrm{FPO}}-\mathrm{FCUO}$.

Change in profit due to changes in the price of electricity in the wholesale electricity market:

$\triangle P U P E=P C 1 \times{ }_{K I U M 1} \times_{R U T 1} \times_{\triangle P E-Q P O} \times_{F R O} \times_{F P 0}-F C U 0$.

Change in profit due to changes in power generation:

$\triangle P U Q P=P C 1 \times K I U M 1 \times R U T 1 \times P E 1-\triangle Q P \times F R O \times F P 0-F C U 0$.

Change in profit due to changes in specific fuel consumption for the production of one kWh of electricity:

$\triangle P U F R=P C 1 \times_{K I U M 1} \times_{R U T} \times_{P E 1}-Q P 1 \times{ }_{\triangle F R} \times_{F P 0}-F C U 0$.

Change in profit due to changes in the specific price of fuel:

$\triangle P U F P=P C 1 \times{ }_{K I U M 1} \times_{R U T 1} \times P E 1-Q P 1 \times{ }_{F R 1} \times_{\triangle F P}-F C U 0$.

Change in profit due to changes in income:

$\triangle P U R U=\triangle R U-Q P O \times_{F R O} \times_{F P O}-F C U O$.

Change in profit due to changes in semi-variable costs:

$\triangle P U V C U=P C 1 \times{ }_{K I U M 1} \times_{R U T 1} \times_{P E 1}-\triangle V C U-F C U 0$.

Change in profit due to changes in fixed costs:

$\triangle P U F C U=P C 1 \times{ }_{K I U M 1} \times_{R U T} \times P E 1-Q P 1 \times F R 1 \times F P 1-\triangle F C U$.

\section{Conclusion}

Thus, the model was built, which included all the relevant factors that affect the profits of an enterprise engaged in electric power generation. The model constructed solves the problem of identifying reserves for profit enterprise on the methodological level.

The main advantages of the model.

1. The model allows you to control the financial result of the company by identifying the factors that have a negative impact on the financial results in a certain period.

2. The model allows the evaluation of the activities related to the increase or decrease of the indicators included in the model.

3. Control of financial results can be monthly, quarterly, annually, which allows to respond quickly to negative changes in the factors.

4. The developed model provides the ability to control the financial results both of the generating enterprise as a whole, and individual station, including several blocks, as well as individual generating unit.

\section{References}

Bogatin YU.V., Shvandar V.A. (1998) Proizvodstvo pribyli [Production of profit]. Moscow, Finance, UNIT.

Bogachev V.N. (1993) O rynochnoy ekonomike i effektivnosti kapitala [About market economy and efficiency of the capital]. Moscow, Finance and statistics.

Borodin A. I., Katkov E. V. (2010) Organization of ensuring processes of innovative development of the enterprises [Organizatsiya obespecheniya innovatsionnogo razvitiya predpriyatiy]. Vestnik REA im. G.V. Plekhanova [The messenger of REA of G. V. 
Plekhanov]. 4, 50-54.

Borodin A.I., Shash N. N., Belokrylova O. S. (2013) Teoreticheskie aspekti upravlehyia finansovim potencialom predpriyatia [Theoretical aspects of management of the financial capacity of the enterprise]. Economy in the industry. 1, 59-645.

Borodin A.I., Shash N. N., Goloshchapova L.V. (2013) Ekonomiko-matematicheskaya model investicionnogo potenciala predpriyatia [Ekonomiko-matematicheskaya model of investment potential of the enterprise]. Economy in the industry. 4, 69-73.

Krylov E.I., Vlasova V.M., Zuravkova I.V. (2005) Analiz finansovykh rezultatov I sebestoimosti produktsii [Analysis of financial results, profitability and product cost] Moscow, Finance and statistics.

Kuzin B., Uriev V., Shakhdinarov G. (2001) Metody i modeli upravleniya firmoy [Методы и модели управления фрирмой] St.Petersburg.

Nechitaylo A. I. (2011) Uchet finansovykh rezultayov $i$ ispolzovaniya pribyli [The accounting of financial results and use arrived]. St.Petersburg.

Ostapenko V.V. (2008) Profit in the industry: formation and growth factors [Pribyl v promyshchlennosti: formirovanie i faktory rosta]. Finansy [Finance].11, 8 - 11.

Uliyanov I.S. (2010) About interrelation between some indicators of rate of return [O vzaimosvyazi mezhdu nekotorymi pokazatelyami normy pribyli].Finansy [Finance].1, 9-13. 